\title{
Toxoplasmosis Seropositivity and Male Sex Hormones
}

\author{
Mustafa Riadh Hussien ${ }^{1 *}$, Adel T M AlSaeed ${ }^{2}$ and Souzan H Eassa ${ }^{3}$ \\ ${ }^{1}$ Department of Microbiology, College of Nursing, Iraq \\ ${ }^{2}$ Department of Microbiology, College of Medicine, Iraq \\ ${ }^{3}$ Department of Immunoparasitology, HOHED, College of Medicine, Iraq
}

Submission: April 09, 2018; Published: November 16, 2018

*Corresponding author: Mustafa RiadhHussien, Department of Microbiology, College of Nursing, Iraq

\begin{abstract}
Background: Toxoplasmosis is a cosmopolitan disease with acute and chronic infections, caused by the obligate intracellular protozoan parasite Toxoplasma gondii that can infect a variety of cells in almost all warm-blooded animals including humans. The study aimed to determine the seroprevalence of T. gondii infection among males in Duhok city using ELISA (IgG and IgM).The relationship between toxoplasmosis and reproductive hormones including testosterone, free testosterone, and Follicle Stimulating Hormone (FSH) levels and its association with male sterility were also investigated.
\end{abstract}

Keywords: Toxoplasmosis; Acute and chronic infection; Male sex hormones

Introduction

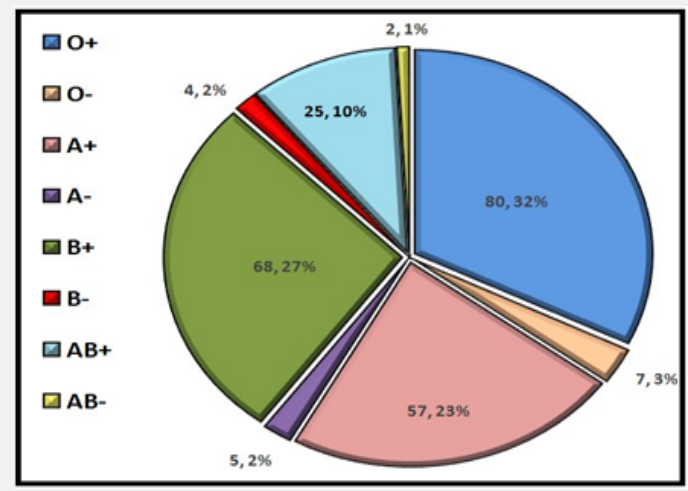

Figure 1: Blood groups distribution among males enrolled in the study.

Regarding Iraq and Kurdistan region, there are limited studies in this direction such as, Mahmood SH [1]who studied (the effect of toxoplasmosis on the level of some male sex hormones in samples from National BloodTransfusion Center/Baghdad) and also BassadA. AL-Aboody[2]in Iraq/Thiqar who studied the (the prevalence of toxoplasmosis among male blood donors). Regarding to Kurdistan, In Kalar city, a study by Al-Bajalan et al. [3] indicated that there is a relationship presence of an association between toxoplasmosis and secondary infertility. Since the prevalence of T. gondii in primary infertile, secondary infertile and fertile males among 260 persons attending the hospital were $45.16 \%, 53.33 \%$, and $47.37 \%$, respectively by using ELISA tests,
respectively(Figure 1).In Duhok province, there is no any study dealing with the effect of toxoplasmosis on the levels of male sex hormones and fertility. Therefore, the main objective of the present study is to find out the correlation between T. gondii infection (acute, chronic), and the levels of serum testosterone, serum follicle stimulating hormone and fertility in a group of healthy blood donor males and those who visited the IVF center of Azadi teaching hospital[4-20](Table1-2).

Table 1: The distribution of the studied males according to their characteristics $(n o=248)$.

\begin{tabular}{|c|c|c|c|}
\hline $\begin{array}{c}\text { Characteristics } \\
\text { of Subjects }\end{array}$ & Groups & N & \% \\
\hline Residence & Urban Rural & 125123 & 50.449 .5 \\
\hline Occupation & Official Private & 134105 & 57.642 .3 \\
\hline \multirow{2}{*}{ Fertility } & Fertile Infertile & 22226 & 89.510 .5 \\
\hline \multirow{5}{*}{ Blood groups } & O+ & 80 & 32.2 \\
\cline { 2 - 4 } & O- & 7 & 2.8 \\
\cline { 2 - 4 } & A+ & 57 & 22.9 \\
\cline { 2 - 4 } & A- & 5 & 27.4 \\
\cline { 2 - 4 } & B- & 4 & 1.6 \\
\cline { 2 - 4 } & AB+ & 25 & 10 \\
\cline { 2 - 4 } & AB- & 2 & 0.8 \\
\cline { 2 - 4 } & & 68 & 2 \\
\hline
\end{tabular}




\begin{tabular}{|c|c|c|c|}
\hline \multirow{3}{*}{ Age groups } & $21-30$ & 63 & 25.4 \\
\cline { 2 - 4 } & $31-40$ & 105 & 42.3 \\
\cline { 2 - 4 } & $41-50$ & 67 & 27 \\
\cline { 2 - 4 } & $51-60$ & 13 & 5.2 \\
\hline
\end{tabular}

Table 2: Statistical distribution of the hormones (TTH, FTH and FSH) characteristics of males enrolled in the study using ELISA IgG and IgM Abs.

\begin{tabular}{|c|c|c|}
\hline Males' Characteristics & Mean & S. D \\
\hline Total Testosterone (ng/ml) & 6.16 & 10.3 \\
\hline Free Testosterone (pg.ml) & 14.81 & 4.71 \\
\hline Follicle-stimulating hormone (IU/ml) & 4.84 & 2.2 \\
\hline Anti-toxoplasma IgM & 0.541 & 0.22 \\
\hline Anti-toxoplasma IgG & 0.625 & 0.75 \\
\hline
\end{tabular}

\section{In order to determine}

a. The rate of Toxoplasma infections among males in Duhok city using ELISA (IgM and IgG).

b. To find out the relationship between toxoplasmosis and blood groups and some demographic factors.

c. To investigate the relationship between toxoplasmosis and sex hormonal disturbances in seropositive males such as, testosterone (total, free) and Follicle Stimulating Hormone (FSH) levels.

\section{Methods and Patients}

Blood samples were collected from 248 apparently healthy males; their ages were between 21 and 60 years. They were attending the In Vitro Fertilization (IVF) center in Azadi Teaching hospital and the Central Blood Bank in Duhok city during the period from November 2016 to the end of July 2017. Before collecting the samples, a questionnaire was prepared and designed which covers various details. From each donor, $5 \mathrm{ml}$ of blood was withdrawn by vein puncture, placed in plain tubes and centrifuged. The serum was dispensed into $1 \mathrm{ml}$ labeled eppendorf tubes and stored at $-20 \mathrm{OC}$ until serological and hormonal tests were performed.Frequency percentage was performed to determine the prevalence of affected persons by $\mathrm{T}$. gondii and mean standard deviation was used to understand the reproductive male hormones concentrations. One-way ANOVA and chi-square tests were performed for statistical analyses. The independent t-tests and chi-square tests were performed to determine the association between toxoplasma and reproductive hormones and infertility[21-35].

\section{Required Kits}

i. The Bioactiva Toxoplasma IgG ELISA (TOXG01) Kit was used.

ii. The Bioactiva Toxoplasma IgM ELISA (TOXM02) Kit was used.

iii. The Monobind Testosterone Enzyme Immunoassay Test Kit (3725-300) was used.

iv. The Monobind Free Testosterone Enzyme Immunoassay Test Kit (5325-300) was used.

v. The MonobindFSH Enzyme Immunoassay Test Kit (425300) was used.

\section{Results}

The mean age of the studied participants was $37.29 \pm 8.07$ years. $22.98 \%$ of male samples appeared to be affected by T. gondii infection. The mean concentrations of the male reproductive hormones were $6.15 \pm 1.03 \mathrm{ng} / \mathrm{ml}$ (total testosterone), $14.81 \pm 4.71 \mathrm{pg} / \mathrm{ml} \quad$ (Free Testosterone), $4.84 \pm 2.20 \quad \mathrm{IU} / \mathrm{ml}$ (Folliclestimulating hormone), $0.54 \pm 0.22(\operatorname{IgM})$, and $0.62 \pm 0.75$ (IgG). A significant difference was found in the samples in terms of infertility $(\mathrm{p}<0.0001)$, while $\mathrm{p}$-values for testosterone $(\mathrm{P}>0.05)$, free testosterone $(\mathrm{P}>0.05)$ and follicle-stimulating hormone $(\mathrm{P}>0.05)$, were non-significant.

\section{Conclusion}

The present study showed a high rate of T. gondii among males in Duhok city with significant difference $(\mathrm{P}<0.05)$ in infertility between T. gondii seropositive and seronegative samples(Tables 3-5).

Table 3: The seropositivity of $T$. gondii with respect to age and other factors.

\begin{tabular}{|c|c|c|c|c|c|}
\hline \multirow{2}{*}{ Patients' Characteristics } & \multicolumn{5}{|c|}{ Rate of Infection (N, \%) } \\
\hline & Overall Seropositive & 22-30 Year & 31-40 Year & 41-50 Year & 51-60 Year \\
\hline Rate of infection & $57(22.98)$ & $14(5.6)$ & $28(11.3)$ & $14(5.6)$ & 1. $(0.4)$ \\
\hline \multirow{2}{*}{ Residence Urban Rural } & $26(10.5)$ & $8(3.2)$ & $12(4.8)$ & $5(2.0)$ & $1(0.4)$ \\
\hline & $31(12.5)$ & $6(2.4)$ & $16(6.4)$ & $9(3.6)$ & $0(0.0)$ \\
\hline \multirow{2}{*}{ Occupation Public Private } & $29(11.6)$ & $9(3.6)$ & $15(6.0)$ & $4(1.6)$ & $1(0.4)$ \\
\hline & $28(11.3)$ & $5(2.0)$ & $13(5.2)$ & $10(4.0)$ & $0(0.0)$ \\
\hline \multirow{2}{*}{ FertilityFertile Infertile } & $53(21.3)$ & $11(4.4)$ & $27(10.8)$ & $14(5.6)$ & $1(0.4)$ \\
\hline & $4(1.6)$ & $3(1.2)$ & $1(.04)$ & $0(0.0)$ & $0(0.0)$ \\
\hline \multicolumn{6}{|l|}{ Blood groups } \\
\hline $0+$ & $18(7.2)$ & $7(2.8)$ & $9(3.6)$ & $2(0.8)$ & $0(0.0)$ \\
\hline
\end{tabular}




\begin{tabular}{|c|c|c|c|c|c|}
\hline O- & $1(0.4)$ & $1(0.4)$ & $0(0.0)$ & $0(0.0)$ & $0(0.0)$ \\
\hline A+ & $9(3.6)$ & $2(0.8)$ & $4(1.6)$ & $1(0.8)$ & $0(0.0)$ \\
\hline A- & $1(0.4)$ & $0(0.0)$ & $1(0.4)$ & $5(2.0)$ & $0(0.0)$ \\
\hline B- & $21(8.4)$ & $3(1.2)$ & $13(5.2)$ & $1(0.4)$ & $0(0.0)$ \\
\hline B- & $2(0.8)$ & $0(0.0)$ & $1(0.4)$ & $3(1.2)$ & $0(0.0)$ \\
\hline AB+ & $4(1.6)$ & $1(1.4)$ & $0(0.0)$ & $1(0.4)$ & $0.0)$ \\
\hline AB- & $1(0.4)$ & $0(0.0)$ & $0(0.0)$ & $0.0)$ \\
\hline
\end{tabular}

Table 4: The mean concentration of TTH and FTH in the sera of the studied males infected with toxoplasmosis using ELISA according to the age group.

\begin{tabular}{|c|c|c|c|c|c|c|}
\hline \multirow{2}{*}{ Age Group Year } & \multicolumn{3}{|c|}{ IgM+ } & \multicolumn{2}{|c|}{ IgG+ } \\
\cline { 2 - 7 } & $\mathbf{N}$ & TTH ng/ml & FTH pg/ml & N & TTH ng/ml & FTH pg/ml \\
\hline $22-30$ & 1 & 9.3 & 30.5 & 12 & 7.68 & 21.44 \\
\hline $31-40$ & 6 & 6.09 & 17.39 & 22 & 6.72 & 17 \\
\hline $41-50$ & 8 & 6.04 & 13.71 & 7 & 0.38 & 0 \\
\hline $51-60$ & 1 & 5.76 & 13.65 & 0 & & \\
\hline Total & 16 & & & 41 & & \\
\hline
\end{tabular}

Table 5: The mean concentration of TTH and FTH in the sera of the studied males infected with toxoplasmosis using ELISA according to the fertility

\begin{tabular}{|c|c|c|c|c|c|c|}
\hline \multirow{2}{*}{ Fertility } & \multicolumn{3}{|c|}{ IgM+ } & \multicolumn{2}{c|}{ IgG+ } \\
\cline { 2 - 7 } & TTH ng/ml & FTH pg/ml & N & TTH ng/ml & FTH pg/ml & N \\
\hline Fertile & 6.1 & 13.72 & 13 & 7.27 & 19.5 & 39 \\
\hline Infertile & 7.29 & 26.61 & 3 & 7.61 & 21.72 & 2 \\
\hline Total & & & 16 & & & 41 \\
\hline
\end{tabular}

\section{Discussion}

\section{Seropositivity of toxoplasma gondii according to age}

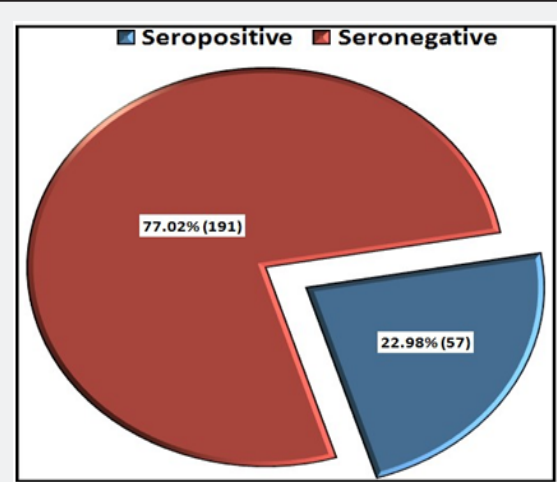

Figure 2: The distribution of studied males according to their seropositivity and seronegativity against toxoplasmosis using ELISA.

The current study showed out of 248 apparently healthy males from different ages (22-60 years) enrolled in this study, $57(22.98 \%)$ were seropositive for $T$. gondii antibodies. The rate of the infection increased with the increase in the age from $5.6 \%$ in the $22-30$ age group to $11.3 \%$ in the $31-40$ age group up to the age group $41-50$ at which was decreased to $5.6 \%$, then dramatically decreased to $0.4 \%$ at the age group 51-60.Various rates of seropositivity of $T$. gondii Abs using different serological tests have been reported among different age groups in previous studies performed in different parts of Kurdistan and Iraq, in some of them higher rates were reported, while in others lower rates than that reported in this study were reported, this might be due to sample size, method of calculation, residency, age, type of test used, or other factors[36-43] (Figures2-3).

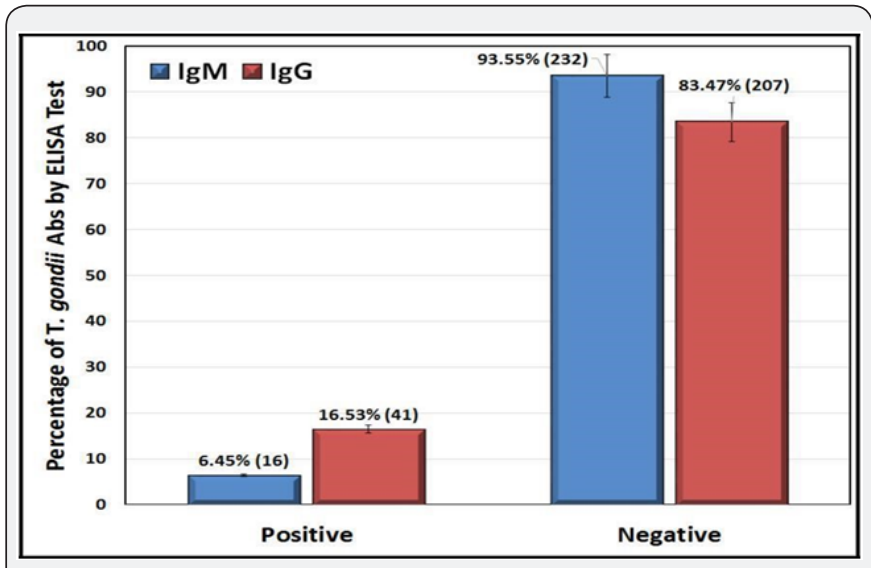

Figure 3: The distribution of the studied males according to their seropositivity of anti Toxoplasma IgG and IgM antibodies using ELISA.

\section{The distribution of toxoplasmosis using ELISA IGG and IGM according to blood group}

This study showed that the overall seropositivity of toxoplasmosis among different blood groups was $22.98 \%$. 
Regarding blood groups, males of group B+aged 31-40 years showed the highest rate(5.2\%) followed by $3.6 \%$ in males of blood group $0+$ of same ages. The present results partly agree with those ofwho found the highest percentage of seropositivity of T. gondii Abs in males of blood groups $\mathrm{O}+$ and $\mathrm{AB}$ which were $35.8 \%$ and $38 \%$, respectively[44-50].

\section{Seropositivity of toxoplasma gondii according to residency}

Regarding residency, the results of the current study on seropositivity of T. gondii in rural and urban areas, showed a high percentage in rural areas[51-53]. It is evident that people living in rural areas are more likely to be affected by different types of infectious microorganism such as, T. gondii due to more contact with animals. Regarding the age, ages from 31-40 and 4150 years showed, higher rates of Toxoplasma Abs(6.4 and 3.6\%, respectively) as compared to urban inhabitants[54-58](Figures $4 \mathrm{~A} \& 4 \mathrm{~B})$.

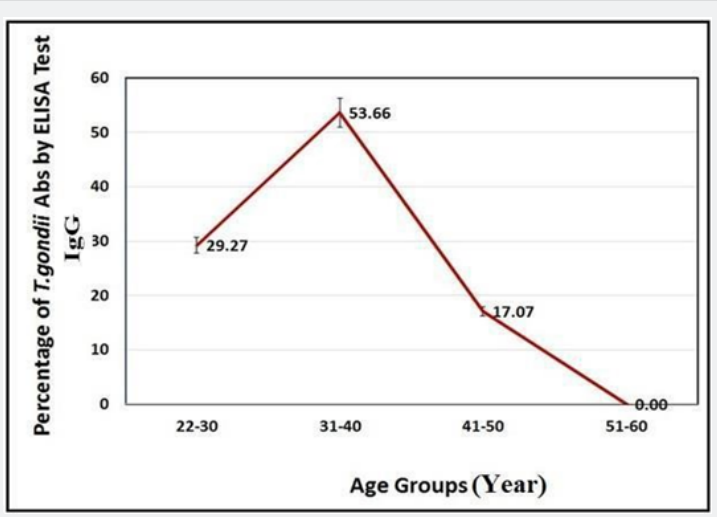

Figure 4a: The distribution of the studied males according to seropositivity of anti-Toxoplasma lgG and age.

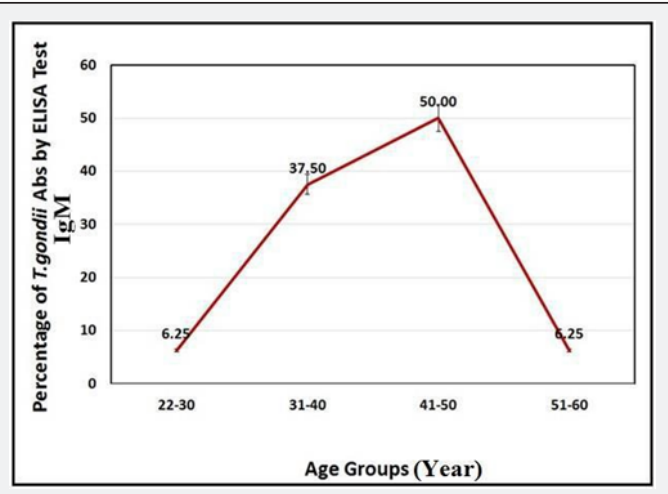

Figure 4b: The percentage distribution of the studied males according to seropositivity of anti-Toxoplasma IgM and age.

\section{Seropositivity of toxoplasma gondii according to occupation}

The results of the present study showed that toxoplasmosis seropositivity was different statistically with respect to occupation for difference of IgG and IgM for official and private occupation. The ages 31-40, 20-30, and 41-50 years in public sectors showed higher percentage of seropositivity $(6.0 \%, 3.6 \%$, and $1.6 \%$ ), respectively and the age group $31-40$ years in private sector (5.2\%) [59-65].

\section{Effects of T. gondiion humans}

The current study concentrated on the effects of $T$. gondii on male reproductive hormones including testosterone, free testosterone, an FSH, as well as, their impact on male fertility. The different aspects of scrutinized characteristics of the patients are analyzed in the following sections(Figures5-7).

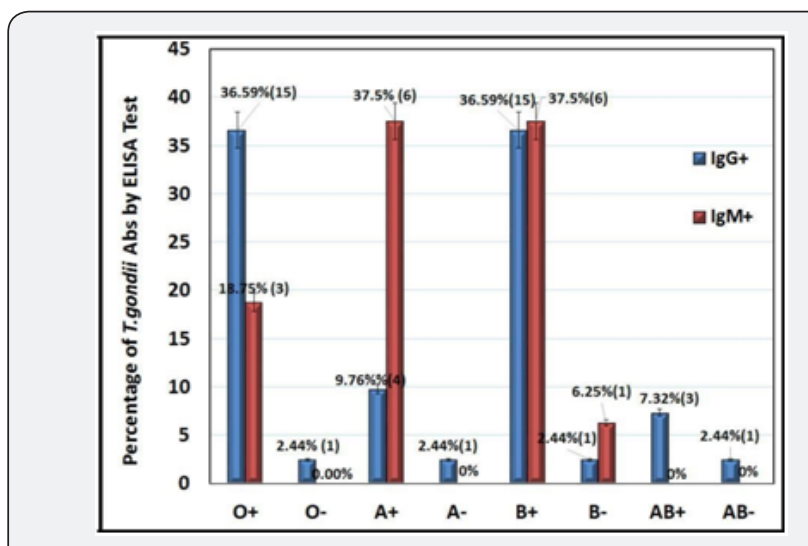

Figure 5: The distribution of seropositivity of toxoplasmosis IgG andlgM Abs among blood groups in studied males.

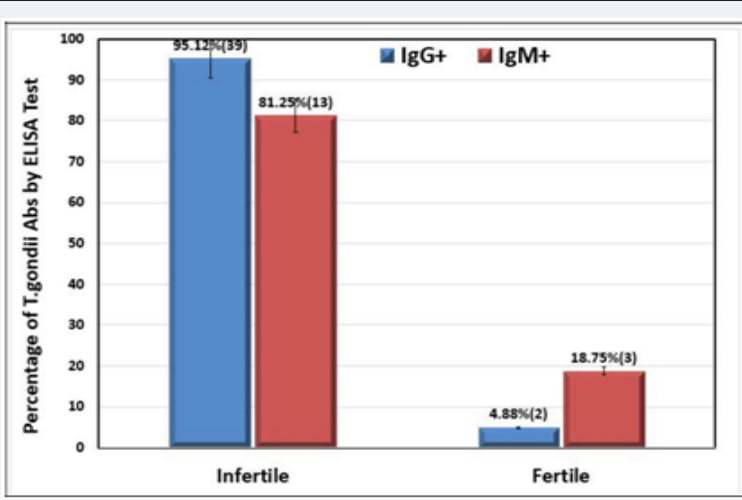

Figure 6: The distribution of the studied males according to Seropositivity of $\lg$ and $\lg M$ Antibodies among fertile and infertile males.

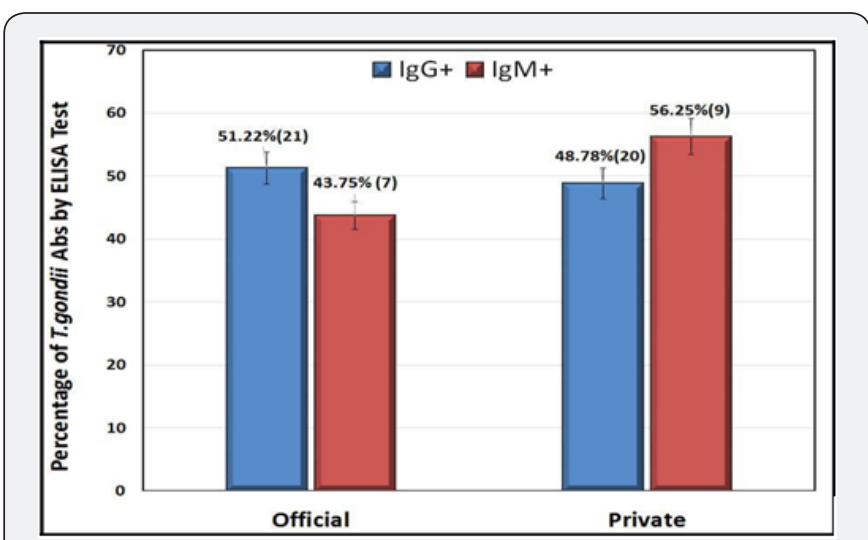

Figure 7: The distribution of the studied males according to seropositivity of toxoplasmosis and occupation. 


\section{The relation between $T$. gondii and reproductive} hormones and fertility in males

The present study showed that there is a significant difference of male reproductive hormones between fertile and infertile males. Male infertility is caused by acquired or congenital urogenital abnormalities, infections in urogenital tract, increase in scrotum temperature, endocrine disturbances, hereditary abnormalities, and immunological factors [66]. Infectious agents such as bacteria, fungi, viruses and parasites are able to interfere with reproductive hormones and functions in male and female populations. The different organs of the male reproductive tract including testis, epididymis, or male accessory sex glands could be affected by infections[67-80](Tables 6-8).

Table 6: The relation between mean concentration of FSH in the sera of the studied males infected with toxoplasmosis from different ages using ELISA test.

\begin{tabular}{|c|c|c|c|c|}
\hline \multirow{2}{*}{ Age Group } & \multirow{2}{*}{$\mathbf{N}$} & IgM+ & \multirow{2}{*}{ N } & IgG+ \\
\cline { 3 - 3 } \cline { 5 - 5 } & & FSH (IU/ml) & & FSH (IU/ml) \\
\hline $22-30$ & 1 & 5.5 & 12 & 6.67 \\
\hline $31-40$ & 6 & 5.07 & 22 & 4.92 \\
\hline $41-50$ & 8 & 5.15 & 7 & 7.85 \\
\hline $51-60$ & 1 & 4.33 & & \\
\hline Total & 16 & & 41 & \\
\hline
\end{tabular}

Table7: The mean concentration of FSH in the sera of the studied males infected with Toxoplasmosis using ELISA according to the fertility.

\begin{tabular}{|c|c|c|c|c|c|c|}
\hline \multirow{2}{*}{ Fertility } & \multicolumn{3}{|c|}{ IgM+ } & \multicolumn{3}{c|}{ IgG+ } \\
\cline { 2 - 7 } & FSH (IU/ml) & $\mathbf{N}$ & $\mathbf{\%}$ & FSH (IU/ml) & $\mathbf{N}$ & \% \\
\hline Fertile & 4.68 & 13 & $81.25 \%$ & 5.9 & 39 & $95.12 \%$ \\
\hline Infertile & 6.87 & 3 & $18.75 \%$ & 6.54 & 2 & $4.88 \%$ \\
\hline Total & & 16 & & & 41 & \\
\hline
\end{tabular}

Table 8: The association of male reproductive hormones with $\mathrm{T}$. gondii and fertility in men aged 22-60 years old.

\begin{tabular}{|c|c|c|c|}
\hline \multicolumn{3}{|c|}{ Reproductive hormones } & P-value (22-60) Years \\
\hline \multicolumn{3}{|c|}{ Testosterone * } & $\mathrm{P}>0.05$ \\
\hline \multicolumn{3}{|c|}{ Free testosterone $*$} & $\mathrm{P}>0.05$ \\
\hline \multicolumn{3}{|c|}{ follicle-stimulating hormone (FSH) * } & $P>0.05$ \\
\hline \multicolumn{3}{|c|}{ Fertility $* *$} & $<0.0001$ \\
\hline Age groups** & \multicolumn{2}{|c|}{ Fertility N (\%) } & \multirow{6}{*}{$<0.0001$} \\
\hline & Fertile & Infertile & \\
\hline $20-30$ & $46(73.0)$ & $17(27.0)$ & \\
\hline $31-40$ & $98(93.3)$ & $7(607)$ & \\
\hline $41-50$ & $66(98.5)$ & $1(1.5)$ & \\
\hline $51-60$ & $12(92.3)$ & $1(7.7)$ & \\
\hline \multicolumn{4}{|c|}{$\begin{array}{l}{ }^{* A N O V A} \text { one way and }{ }^{* *} \text { chi-square tests were performed for statistical } \\
\text { analyses }\end{array}$} \\
\hline
\end{tabular}

The present study showed that the males infected with toxoplasmosis had the highest significant differences $(\mathrm{P}<0.001)$ with the mean concentration of serum FTH. Males with seropositive anti-Toxoplasma IgG antibodies and anti- Toxoplasma
IgM antibodies revealed the highest mean concentration levels of $19.61 \mathrm{pg} / \mathrm{ml}$ and $16.13 \mathrm{pg} / \mathrm{ml}$ for FTH hormones. While TTH and FSH hormone showed nonsignificant difference $(\mathrm{P}>0.05)$ for the mean concentration between acute and chronic males infected with toxoplasmosis[81-100] (Table 9).

Table 9: The association in men according to residency and occupation.

\begin{tabular}{|c|c|c|c|}
\hline $\begin{array}{c}\text { characteristics } \\
\text { of Males }\end{array}$ & Fertile N (\%) & Infertile N (\%) & P-value \\
\hline \multirow{2}{*}{$\begin{array}{c}\text { Residence } \\
\text { Urban } \\
\text { Rural }\end{array}$} & $114(51.4)$ & $11(42.3)$ & $0.383^{*}$ \\
\cline { 2 - 4 } & $108(48.6)$ & $15(57.76)$ & \\
\hline $\begin{array}{c}\text { Occupation } \\
\text { Official } \\
\text { Private }\end{array}$ & $125(56.3)$ & $18(69.2)$ & $0.207^{*}$ \\
\cline { 2 - 4 } & $97(43.7)$ & $8(30.8)$ & \\
\hline \multicolumn{3}{|c|}{$*$ chi-square test was performed } \\
\hline
\end{tabular}

\section{Conclusion}

From the present study, the followings are concluded:

I. The overall seropositivity rate of T. gondii was $22.98 \%$ in the tested sample, $6.45 \%$ with acute and $16.35 \%$ with chronic toxoplasmosis.

II. Regarding age, the highest rate (11.3\%) of toxoplasmosis was among the age group 31-40years.

III. Males with $\mathrm{O}+$ and $\mathrm{B}+$ blood groups showed higher percentage of infection with Toxoplasma in comparison to other blood groups[101-130].

IV. Infertile males had higher percentage of both acute and chronic toxoplasmosis(Figures 8-9).

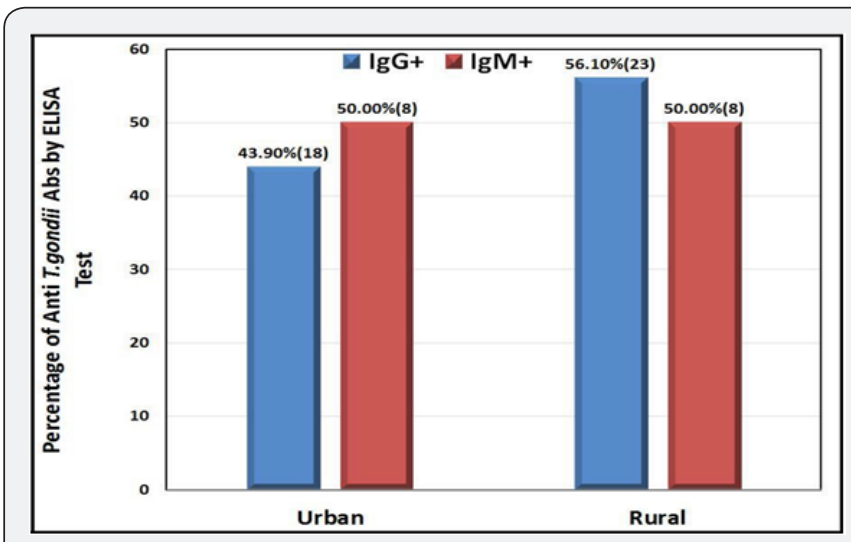

Figure 8: The distribution of Toxoplasmosis IgG and IgM Abs seropositivity according to residency.

V. Official workers showed a higher rate $(51.22 \%)$ of chronic toxoplasmosis than private worker (48.78\%), while acute infection was higher $(56.25 \%)$ in private workers than official (43.75\%).

VI. Rural inhabitants revealed high rates of both acute and chronic toxoplasmosis, in comparison to urban inhabitants. 


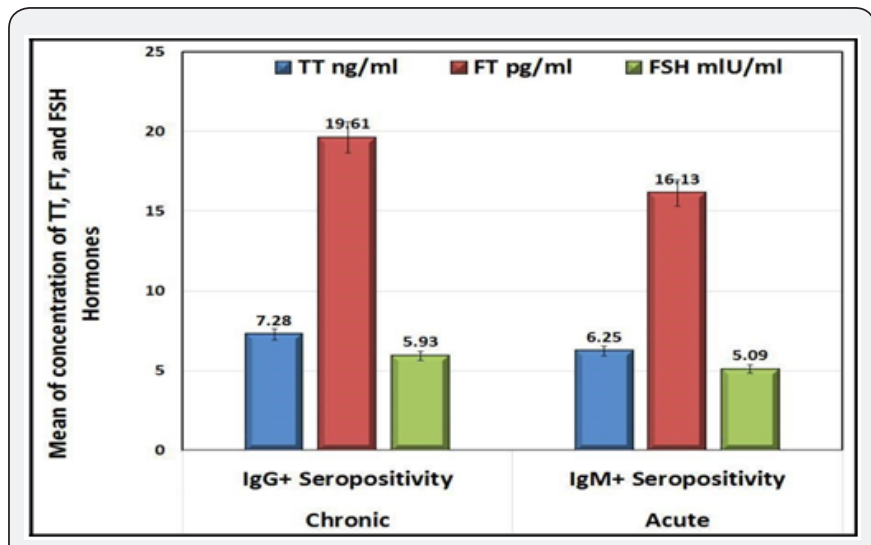

Figure 9: The mean concentration of sex hormones (TTH, FTH and $\mathrm{FSH}$ ) in the sera of the studied males infected with acute ( $\operatorname{lgM})$ and chronic (IgG) toxoplasmosis using ELISA.

VII. The age group 22-30 year scored higher mean concentration of TT and FT in both acute and chronic infected males, while the age group 51-60 years showed a lower mean concentration of TT and FT in both acute and chronic infected males[131-140].

VIII. The TT and FT hormone levels recorded highest significant differences between fertile and infertile males. According to acute toxoplasmosis the infertile males showed a higher mean concentration of both TT and FT hormones. While, fertile cases, showed lowest significant differences.

IX. FSH showed higher value (6.87 and $6.54 \mathrm{IU} / \mathrm{ml}$ ) and (4.68 and $5.9 \mathrm{IU} / \mathrm{ml}$ ) for acute and chronic toxoplasmosis in infertile and fertile men, respectively[141-152].

\section{References}

1. Al-Saadii, SHM (2013) The Effect of Toxoplasmosis on The Level of Some Male Sex Hormones in Samples from National Blood Transfusion Center/Baghdad M.Sc. thesis. College of Science/ University of Baghdad.

2. Bassad, Aboody Al (2015)Prevalence study of toxoplasmosis among males blood donors in thi-qar province-Iraq. IMPACT: International Journal of Research in Applied, Natural and Social Sciences (IMPACT: IJRANSS) 3(11): 73-82.

3. Al-Bajalan RR, Al-Nasiri FS, Mahmood SM (2015) Detection of Toxoplasma gondii by Latex and ELISA Test in Infertile and Fertile Men in Kalar City, Kurdistan Region, Iraq. International Journal of Current Microbiology and Applied Sciences 4(10): 570-585.

4. Abdoli A (2014) Toxoplasma, testosterone, and behavior manipulation: the role of parasite strain, host variations, and intensity of infection. Frontiers in biology 9(2): 151-160.

5. Abdoli A,Dalimi A,Movahedin M(2012) Impaired reproductive function of male rats infected with Toxoplasma gondii. Andrologia 44(s1): 679687

6. Abdul-Aziz AI, Zghair KH (2014) Study of Epidemiology of Toxoplasmosis in Hemodialysis Patients in Baghdad Hospitals. Iraqi Journal of Science 55(3B): 1236-1242.

7. Abdul-LateefHI(2011) ThelevelsofIFN-gamma,IL-12AndTestosterone Hormone in Persons withAsymptomaticToxoplasmosis.M.Sc.Thesis. College of Science in Medical Microbiology, University of Baghdad: 102.
8. Abdulla HE, Al-Bashier NM, Al-Kawaz U, Al-Shuwaikh AMA,Abood AS (2015) Cross-sectional study of infertile males with Toxoplasmosis in Baghdad province. International Journal of Scientific and Engineering Research 6(1): 254-259.

9. Abu-Madi MA, Behnke JM, Dabritz HA (2010) Toxoplasma gondii seropositivity and co-infection with torch pathogen in high risk patients from Qatar. Am J Trop MedHyg 82(4):626-633.

10.Abubaker S, Dakhil V(2008) Seroprevalence of Toxoplasmosis in Women with Spontaneous Abortion. Zanco Journal of Medical Sciences12(2): 48-54.

11. Ahmed SA, GogalRM,Walsh JE,Saunders G (1996) Estrogen induces defects in T cell functions of mice. Fed AmSociExp Bio J 10:961.

12. Al- DalawiNKE (2007) Hormonal disturbances in suddenly and previously aborted women affected with toxoplasmosis in Baghdad province. M.Sc. Technical Foundation College of Health and Medical Technology. Technical Foundation. PP. 125.

13. Al-Dujaily, KYA(1998) Seroepidiomiological study of Toxoplasmosis among Aborted women in Baghdad. M.Sc., College of Veterinary Medicine/ University of Baghdad. PP. 123.

14. Jubori AL, AR M, (2005) Serological of toxoplasmosis in Kirkuk province. MSc Thesis. College of Health and Medical Technology. PP. 82.

15. Al-Kaysi AM, NM Ali (2010) Serological and biochemical study of HBV, HCV, HIV and toxoplasmosis infection among blood donors in Iraq. Egyptain Journal of Comparative Pathology And Clinical Pathology 23(1): 1-9.

16. Al-QurashiAR (2004) Seroepidemiological study of toxoplasmosis in rural areas in the eastern region of Saudi Arabia. J Egypt Soc Parasitol 34(1): 23-34.

17. AlRawiKH (2009) Detection of B gene from blood of pregnant and abortive women infected with Toxoplama gondii. Ph.D. Thesis. Collage of Science.University of Baghdad. PP. 125.

18. Al-Saadi AaM,Qasim MJ, Jebri NN (2013) Affliction with toxoplasmosis among infertile men in Kamal Al-Samaraee Hospital. Baghdad City. AlTaqani 26(3): 56-63.

19. Al-Saeed ATM, Eassa SH, Murad MA (2016) Detection of toxoplasmosis among women with abortion using molecular and serological tests in Duhok City. DMJ 10(2): 56-68.

20. Al-Shikhly MA (2010)Early detection of toxoplasmosis percentage in premarital females by immunological methods. M.Sc. Thesis. College of Science.University of Baghdad pp. 147.

21. Al-Shikly MA (2008) Serological study of Toxoplasma gondii antibodies in some Universities students in Baghdad province. M.Sc. thesis. College of Science. University of Baghdad pp. 102.

22. Al-Timimi RL (2004) Detection of toxoplasmosis among different groups of aborted women during gestational age of pregnancy. Diploma, Thesis. College of Health and Medical Technology pp. 77.

23. Al-Ubaydi GT (2004) Toxoplasmosis in pregnant women and its relation with some parameters. M.Sc. Thesis. College of Science. University of Mosul. pp.127.

24.Al-Warid HS, Al-Qadhi BN (2012) Evaluation of progesterone and estrogen hormonal levels in pregnant women with toxoplasmosis. Eur J Sci Res 91(4): 515-519.

25. Altigany I, Ahmed SA, Abdrabo AEA (2014) Assessment of Testosterone Hormone Level in Patients with Toxoplasmosis Attending Omdurman Military Hospital. International Journal of Science and Research (IJSR) 4(12): 52-54.

26. Alwachi SN (2003) Biology. Daralfiker for printing and publishing, Amman, Jordan. (In Arabic). PP. 270. 
27. Arantes TP, Lopes WD, FerreiraRM, Pieroni JS, Pinto VM, et al. (2009) Toxoplasma gondii: Evidence for the transmission by semen in dogs. Experimental parasitology 123(2): 190-194.

28. Arens J, Barnes K, Crowley N, Maartens G (2007) Treating AIDSassociated cerebral toxoplasmosis-pyrimethamine plus sulfadiazine compared with cotrimoxazole, and outcome with adjunctive glucocorticoids: South African Medical Journal 97(10): 956-958.

29. Ashraf M, Abdul-Haleem SA (2010) Seroprevalence of Anti-Toxoplasma gondii IgG and IgM Among Pregnant Women in Sana'a Capital and Capital Trusteeship. Scientific Journal of King Faisal University (Basic and applied Sciences) 11(2):179-188.

30. August JR (2009) Consultations in Feline Internal Medicine,Elsevier Health Sciences6: PP. 208.

31. Bahia-Oliveria LM, Jones JL, Azevedo-Silva J,Aleves CC,Orefice F, et al. (2003)Highly endemic, waterborne toxoplasmosis in north Rio de Janeiro state, Brazil. Emerg Infect Dis 9(1):55-62.

32. Bakre HM (2016) Serological tests and polymerase chain reaction for detection of Toxoplasma gondii infection in women attending for premarital examination. Zanco Journal of Medical Sciences 20(3): $1476-1484$.

33. Bakre HM, Hussain SK, Ali SK (2014) Toxoplasma gondii infection in patients with schizophrenia.Zanco Journal of Medical Sciences 19(1):874-879

34. Bassil N,Alkaade S, MorleyJE (2009) The benefits and risks of testosterone replacement therapy: a review. Ther Clin Risk Manag 5(3): 427-448.

35. Bhopale GM (2003) Pathogenesis of toxoplasmosis. Comparative immunology, microbiology and infectious diseases 26(4): 213-222.

36. Bobić B, Klun I, Nikolić A,Djurković-Djaković O (2012) Toxoplasma gondii-infection in south-east Europe: epidemiology and epizootiology. Toxoplasmosis-Recent Advances: 37-54.

37. Brown WM, Hines M, Fane BA, Breedlove SM (2002) Masculinized finger length patterns in human males and females with congenital adrenal hyperplasia. HormBehav42(4): 380-386.

38. Buffolano W, Gilbert RE, Holland FJ, Fratta D, Palumbo F, et al.(1996) Risk factors for recent Toxoplasma infection in pregnant women in Naples. Epidemiol Infect 116(3): 347-351.

39. Buxton D (1998) Protozoan infections (Toxoplasma gondii, Neospora caninum and Sarcocystis spp.) in sheep and goats: recent advances. Veterinary research 29(3): 289-310.

40. Carruthers VB (2002) Host cell invasion by the opportunistic pathogen Toxoplasma gondii. Acta tropica 81(2): 111-122.

41. Cartron JP (1994) Defining the Rh blood group antigens: biochemistry and molecular genetics. Blood Rev 8(4): 199-212.

42. Coêlho RA, Kobayashi M, Carvalho LB Jr(2003) Prevalence of IgG antibodies specific to Toxoplasma gondii among blood donors in Recife, Northeast Brazil. Rev Inst Med Trop Sao Paulo 45(4): 229-231.

43. Colosi HA, Jalali-Zadeh B, Colosi IA, Simon LM, Costache CA (2015) Influence of Toxoplasma gondii Infection on Male Fertility: A Pilot Study on Immunocompetent Human Volunteers. Iran J Parasitol10(3): 402-409.

44. CookAJ, Gilbert RE, Buffolano W (2000). Sources of Toxoplasma infection in pregnant women: European multicentre case-control studyCommentary: Congenital toxoplasmosis-further thought for food. Bmj 321(7254): 142-147.

45. Cox FE (2002) History of human parasitology. Clin Microbiol Rev 15(4): 595-612.
46. Craven AJ, Nixon AJ, Ashby MG, Ormandy CJ, Blazek K, et al. (2006) Prolactin delays hair regrowth in mice. J Endocrinol 191(2): 415-425.

47. Dalgıç N (2008) Congenital Toxoplasma gondii infection. Marmara Medical Journal 21(1): 89-101.

48. Dalimi A, Abdoli A (2013) Toxoplasma gondii and male reproduction impairment: a new aspect of toxoplasmosis research. Jundishapur Journal of Microbiology6(8).

49. Drop SL, De Waal WJ, De Muinck Keizer-Schrama SM (1998) Sex Steroid Treatment of Constitutionally Tall Stature. Endocrine Reviews 19(5): 540-558.

50. Dubey J (2007) The history and life cycle of Toxoplasma gondii. Toxoplasma gondii: 1-17.

51. Dubey J (2009) History of the discovery of the life cycle of Toxoplasma gondii. Int J Parasitol39(8): 877-882.

52. Dubey J, Hill D (2002) Toxoplasma gondii: Transmission and Prevention. Clin Microbiol Rev 8(10): 634-640.

53. Dubey J, Jones J (2008)Toxoplasma gondii infection in humans and animals in the United States. Int J Parasitol 38(11): 1257-1278.

54. Dubey JP(2008) The history of Toxoplasma gondii-the first 100 years. J Eukaryot Microbiol 55(6): 467-475.

55. Eslamirad Z, Hajihossein R, Ghorbanzadeh B, Alimohammadi M, Mosayebi M, et al., (2013) Effects of Toxoplasma gondii Infection in Level of Serum Testosterone in Males with Chronic Toxoplasmosis. Iran J Parasitol 8(4): 622-626.

56. Eslamirad Z, Hajihossein R, Gorbanzadeh B, AlmasiHashianee A (2014) Relationship between blood testosterone level and lipid profile among a group of men with and without Toxoplasma IgG antibody referred to pre-marital clinics in Arak city, 2012. Arak Medical University Journal16(12): 1-8.

57. Flegr J (2007) Effects of Toxoplasma on human behavior. Schizophr Bull 33(3): 757-760.

58. Flegr J, Hrdá S, Kodym P (2005) Influence of latent'asymptomatic' toxoplasmosis on body weight of pregnant women. Folia Parasitol (Praha) 52(3): 199-204.

59. Flegr J,Lindová J, Kodym P (2008) Sex-dependent toxoplasmosisassociated differences in testosterone concentration in humans. Parasitology 135(4): 427-431.

60. Garcia JL (2009)Vaccination concepts against Toxoplasma gondii. Expert Rev Vaccines 8(2): 215-225.

61. Garratty G, Postoway N, Nance SJ, Brunt DJ (1984) Spontaneous agglutination of red cells with a positive direct antiglobulin test in various media. Transfusion 24(3): 214-217.

62. Gazzinelli RT, Amichay D, Sharton-Kersten T, Grunwald E, Farber JM, et al. (1996) Role of macrophage-derived cytokines in the induction and regulation of cell mediated immunity to Toxoplasma gondii. Current Topics in Microbiology and Immunology $219: 127-139$.

63. Giannoulis C, Zournatzi B, Giomisi A, Diza E, Tzafettas I (2008) Toxoplasmosis during pregnancy: a case report and review of the literature. Hippokratia 12(3):139-143.

64. Gill HS (1985) Occurrence of Toxoplasma gondii antibodies in Tanzanian blood donors. East African medical journal 62(8): 585-591.

65. Dohle GR, Colpi G, Hargreave T, Papp G, Jungwirth A, et al. (2005) EAU guidelines on male infertility. European urology 48(5): 703-711.

66. Gilot-Fromont E, Mercier A, Gotteland C, Richomme C, Aubert D, et al. (2012) The life cycle of Toxoplasma gondii in the natural environment, INTECH Open Access Publisher. 
67. Guyton A (1986) Textbook of Medical Physiology ( $7^{\text {th }}$ edn) Saunders. PA: 276, Philadelphia, USA.

68. Hakomori S (1999) Antigen structure and genetic basis of histoblood groups A, B and O: their changes associated with human cancer BiochimBiophys Acta 1473(1): 247-266.

69. Hamad NR, KadirMA (2013) Prevalence and comparison between the efficacy of different techniques for diagnosis of Toxoplasma gondii among women in Erbil province-Iraqi Kurdistan. European Scientific Journal 3(1): 901-908.

70. Henry L, Beverley KA (1976) Age and sex differences in the response of lymph node post-capillary venules in mice infected with Toxoplasma gondii. British journal of experimental pathology 57(3): 274-280.

71. Hill D, Dubey JP (2002) Toxoplasma gondii: transmission, diagnosis and prevention. Clin Microbiol Infect 8(10): 634-640.

72. Hill DE, Chirukandoth S, Dubey JP (2005) Biology and epidemiology of Toxoplasma gondii in man and animals. Animal Health Res Rev 6(1): 41-61.

73. Hodková H, Kolbeková P, Skallová A, Lindová J, Flegr J (2007)Higher perceived dominancein in Toxoplasma infected men the new evidence for role of increased level of testosterone in toxoplasmosis-associated changes in human behavior. Neuro Endocrinol Lett 28(2): 110-114.

74. Hunter CA, Sibley LD (2012) Modulation of innate immunity by Toxoplasma gondii virulence effectors. Nat Rev Microbiol; 10(11): 766-778.

75. Issit PD (1985) Applied Blood Group Serology ( $3^{\text {rd }}$ edn). Montgomery Scientific, Miami, USA.

76. Jackson M, HutchisonW (1989) The prevalence and source of Toxoplasma infection in the environment. Advances in parasitology 28: 55-105.

77. Jafari R, Sadeghpour S, Sharifi F, Darani HY, Bagherpour B, et al. (2016) Anti-Toxoplasma IgM and IgG Seropositivity Among Individuals Referred to a Clinical Laboratory of Isfahan, Central Iran. International Journal of Infection; In press.

78. James WH (1996) Evidence that mammalian sex ratios at birth are partially controlled by parental hormone levels at the time of conception. J Theor Biol 180(4): 271-286.

79. James WH (1986) Hormonal control of sex ratio. J Theor Biol 118(4): 427-441.

80. Jassam FS (2010) Relationship between toxoplasmosis and testosterone hormone among schizophrenic patients in Baghdad. M. Sc. Thesis. College Council of Health and Medical Technology. PP 81.

81. Jones JL, Holland GN (2010) Annual burden of ocular toxoplasmosis in the United States. Am J Trop Med Hyg 82(3): 464-465.

82. Jones JL, Kruszon-Moran D, Wilson M, Mcquillan G, Navin T, et al. (2001) Toxoplasma gondii infection in the United States: seroprevalence and risk factors. Am J Epidemiol 154(4): 357-365.

83. Jones JL, Muccioli C, Belfort R, Holland GN, Roberts JM, et al. (2006) Recently Acquired Toxoplasma gondii Infection, Brazil. Emerging Infectious Disease journal-CDC 12(4): 582-587.

84. Jones JL, Ogunmodede F, Scheftel J, Kirkland E, Lopez A, et al. (2003) Toxoplasmosis-related knowledge and practices among pregnant women in the United States. Infectious diseases in obstetrics and gynecology 11(3): 139-145.

85. Joseph B, Deepika S, Richard HS (2010) Toxoplasmosis. Web professional. Industry spotlight. Available.
86. Jumaian NF (2005) Seroprevalence and risk factors for Toxoplasma infection in pregnant women in Eastern Jordan. Med.Health J 11(1-2): 45-51.

87. Jungwirth A, Diemer T, Dohle GR, Giwercman A, Kopa ZC, et al. (2015) Guidelines on Male Infertility (Report). Brussels.

88. Kadhim RA, Al-Awadi HM (2013) Changes in Testosterone, Progesterone and Prolactin Levels in Pregnant Women with Chronic Toxoplasmosis. Med. J. Babylon 10(3): 699-709.

89. KaňkováŠ, Kodym P, Flegr J (2011) Direct evidence of Toxoplasmainduced changes in serum testosterone in mice. Experimental parasitology 128(3): 181-183.

90. Kapperud G, Jenum PA, Stray-pedersen B, melby KK, Eskild A (1996) Risk factor for Toxoplasma gondii infection in pregnancy. Results of aprospective case-control study in Norway. Am. J. Epidemiol. 144(4): 405-412.

91. Kareem S (2008) Prevalence, serodiagnosis and some immunological aspects of toxoplasmosis among women in Baghdad province. M.Sc. Thesis. College of health and Medical Technology. Technical Foundation pp: 104.

92. Kawashima T, khin-Sane W, Kawabata M, Barzaga N, Matsuda H, et al. (2000) Prevalance of antibodies to Toxoplasma gondii among urban and rural residents in the Philippines South east Asian. J Trop Med Public Health 31: 742-746.

93. Khalil HI (2008) Some aspects in Seroprevalence, diagnosis and influence of sex hormones on immunity during human toxoplasmosis. Ph.D. Thesis, College of Medicine. University of AL-Mustansiriyah pp. 173.

94. Kirkwood BR, Sterne JA (2010) Essential medical statistics, John Wiley and Sons.

95. Kittas C, Henry L (1980) Effect of sex hormones on the response of mice to infection with Toxoplasma gondii. British journal of experimental pathology 61(6): 590-600.

96. Lappalainen M, Hedman K (2004) Serodiagnosis of toxoplasmosis. The impact of measurement of IgG avidity. Ann Ist Super Sanita 40(1): 8188.

97. Larosa DF, Stumhofer JS, Gelman AE, Rahman AH, Taylor DK, et al. (2008) T cell expression of MyD88 is required for resistance to Toxoplasma gondii. Proceedings of the National Academy of Sciences 105(10): 3855-3860.

98. Lecolier B, Grynberg H, Freund M (1990) Absence of relationship betweenToxoplasma gondii antibodies and blood group in pregnant women in France. European Journal of Clinical Microbiology and Infectious Diseases 9(2): 152-153.

99. Leite M, Siciliano S, Rocha LSA, Justa TR, César KR, et al. (2008) Correlation between specific IgM levels and percentage IgG-class antibody avidity to Toxoplasma gondii. Revista do Instituto de Medicina Tropical de São Paulo 50(4): 237-242.

100. Liesenfeld O, Montoya JG, Tathineni NJ, Davis M, Brown BW, et al. (2001) Confirmatory serologic testing for acute toxoplasmosis and rate of induced abortions among women reported to have positive Toxoplasma immunoglobulin M antibody titers. American journal of obstetrics and gynecology 184(2): 140-145.

101. Liu Q Wang ZD, Huang SY, Zhu XQ (2015) Diagnosis of toxoplasmosis and typing of Toxoplasma gondii. Parasites and vectors; 8(1): 292.

102. López R, Fano R, Contreras R, Font L (1993) Anticuerpos IgG antiToxoplasma gondii en Cubanos donantes de sangre. Rev Lat Amer Microbiol 35: 207-210. 
103. Luft BJ, Chua A (2000) Central nervous system toxoplasmosis in HIV Pathogenesis, diagnosis, and therapy.Curr InfectDisRep 2(4): 358362 .

104. Lutchmaya S, Baron-Cohen S, Raggatt P, Knickmeyer R, Manning JT (2004) Second to fourth digit ratios, fetal testosterone and estradiol. Early Human Dev77(1-2): 23-28.

105. Machattie C (1938)Notes on two cases of naturally occurring toxoplasmosis in Baghdad. Tran. RoyTropHyg23:373-376.

106. Malarvizhi A, ViswanathanT, LavanyaV, Moorthy K (2012) Seroprevalence of Toxoplasma gondii in pregnant women. Journal of public health and epidemiology4(6): 170-177.

107. MalikA, RizviM, Khan F, Khan N, Rabbani T, et al. (2014)Toxoplasma gondii in women with bad obstetric history and infertility: a five-year study. Asian Pacific Journal of Tropical. Disease 4(1): S236-S239.

108. Markus MB(2003) Toxoplasma gondii. In: MiliotisMDand BIER JW(Eds.) International handbook of foodborne pathogens. New York: CRC Press, pp. 511-523.

109. Martinez-Garcia F, Regadera J, Mayer R, Sanchez S, Nistal M (1996) Protozoan infections in the male genital tract. J urol 156(2): 340-349.

110. Midtvedt T, Vaage L (1989) Relationship between Toxoplasma gondii antibodies and blood group. Eur J Clin Microbiol Infect Dis 8(6): 575 576 .

111. Montoya JG, OLiesenfeld (2004) Toxoplasmosis. The Lancet 363(9425): 1965-1976

112. Montoya JG, JSRemington (1995)Studies on the serodiagnosis of toxoplasmic lymphadenitis. Clin infect dis20(4): 781-789.

113. Montoya JG, FRosso (2005) Diagnosis and management of toxoplasmosis. Clin perinatal 32(3): 705-726.

114. Mooradian AD, Morley JE, Korenman SG (1987)Biological actions of androgens. EndocrRev 8(1): 1-28.

115. Neave N, LaingS, Fink B, Manning JT(2003) Second to fourth digit ratio, testosterone and perceived male dominance. Proc Biol Sci 270(1529): 2167-2172.

116. Nelson RJ (2005) An introduction to behavioral endocrinology ( $3^{\text {rd }}$ edn). Sunderland, Mass: Sinauer Associates.Inc. pp. 143.

117. Niazi AD, MW N, saif SA, AbbassAF, Gzar(1992)Prevalence of Toxoplasma antibodies in Iraqi population. J Fac Med Baghdad34(3): 255-261.

118. Ökten A, Kalyoncu M, YarișN(2002) The ratio of second-and fourth-digit lengths and congenital adrenal hyperplasia due to 21-hydroxylase deficiency. Early hum dev 70(1): 47-54.

119. OktenliC, L DogansiT,Ozgurtas(2004) Transient hypogon- adotrophic hypogonadism in males with acute toxoplasmosis: suppressive effect of interleukin-1 $\beta$ on the secretion of GnRH. Human Repro19(4):859-866.

120. Pappas G, Roussos N, Falagas ME(2009) Toxoplasmosis snapshots: global status of Toxoplasma gondii seroprevalence and implications for pregnancy and congenital toxoplasmosis. Int J Parasitol39(12): 1385-1394.

121. Pellati D, Mylonakis I, Bertoloni G, Fiore C, Andrisani A et al. (2008) Genital tract infections and infertility. Eur J Obstet Gynecol Reprod Biol 140(1): 3-11.

122. Pergola G, Cascone A, Russo M (2010)Acute pericarditis and myocarditis by Toxoplasma gondii in an immunocompetent young man: a case report. Infez Med18(1): 48-52.
123. Petersen E (2007) Toxoplasmosis. Seminars in Fetal and Neonatal Medicine12(3): 214-223.

124. Race RR, R Sanger (1975)Blood groups in man. ( $6^{\text {th }}$ edn). Oxford, Published by Blackwell Scientific Publications.

125. RäisänenS (1978) Toxoplasmosis transmitted by blood transfusions Transfusion 18(3): 329-332.

126. Razzak A H, SAWais, AYSaeid(2005)Toxoplasmosis: the innocent suspect of pregnancy wastage in Duhok, Iraq. East Mediterr health J11(4): 625- 632.

127. Remington JS, EsmontsGD (1990)Toxoplasmosis In: JS Rem- ington and JOklein(Eds). Infectious Disease of the fetus and New born Infant.WB Saunders. London, pp. 89-195.

128. RemingtonJS, R McLeod, PThulliez, GDesmonts(2005)Toxoplasmosis. In: JS Remington. Infectious Diseases of the fetus and newborn infant,WBSaunders Company Philadelphia, pp.947-1091.

129. Rodrigues A, SUezatos, MVono, TPandossio, LSpegiorinA,OlianiD, et al (2011)Association between anti- Toxoplasma gondii antibodies and ABO blood group system.JVenomAnimToxinTropDis17(2):184-189.

130. Roitt I, J Brostoff,D Male(2001)Parasitology and Vector biolgy, (2 $2^{\text {nd }}$ ed). Academic Press. pp165-178.

131. Sabin AB, Feldman HA (1948) Dyes as microchemical indicators of a new immunity phenomenon affecting a protozoon parasite (Toxoplasma). Science 108(2815): 660-663.

132. SalibayCC, CADung,FG Claveria(2008)Serological survey of Toxoplasma gondii infection among urban.(Manila)and suburban (Dasmarinas,cavite) Residents, Philippines JprotozolRes 18:26-33.

133. SenthamaraiS,SivasankariS,Apurba S, Sandhya B,KumudavathiM, et al. (2013)Seroprevalence of toxoplasmosis in pregnant women with bad obstetric history in a tertiary care hospital, Kanchipuram-a pilot study. Disease 3(9): 29-32.

134. SherA (1998) Ignition of the type 1 response to intracellular infection by dendritic cell-derived interleukin-12. Eur cytokine netw9(3 Suppl): 65-68.

135. Shin DW, Cha DY, Hua QJ, Cha GH, Lee YH (2009) Seroprevalence of Toxoplasma gondii infection and characteristics of seropositive patients in general hospitals in Daejeon, Korea.Korean j parasitology 47(2): 125-130.

136. Siddiqui N, Shujatullah F, Khan HM, Rabbani T, Khan PA (2014) IgG avidity antibodies against Toxoplasma gondii in high risk females of reproductive age group in India.Korean J parasitol52(5): 487.

137. Sinisi AA, Di Finizio B, Pasquali D, Scurini C, D Apuzzo A, et al.(2003) Prevalence of antisperm antibodies by SpermMARtest in subjects undergoing a routine sperm analysis for infertility. Int J Androl16(5): 311-314.

138. Sukthana Y (2006) Toxoplasmosis: beyond animals to humans Trends Parasitol 22(3): 137-142.

139. Swai ES, Schoonman L(2009) Seroprevalence of Toxoplasma gondi infection amongst residents of Tanga district in north-east Tanzania. Tanzanhealth Res 11(4): 205-209.

140. Szekeres-BarthoJ, Polgar B (2010)Chapter 8: Progesterone Pregnancy, and Innate Immunity. In: KLEIN SL and Roberts, CW(eds.) Sex hormones and immunity to infection. Springer, USA.

141. Tenter AM, Heckeroth AR, Weiss LM (2000) Toxoplasma gondii: from animals to humans. Int j parasitol 30(12): 1217-1258.

142. Terpsidis KI, Papazahariadou MG, Taitzoglou IA, Papaioannou NG, Georgiadis MP, et al. (2009) Toxoplasma gondii: reproductive 
parameters in experimentally infected male rats. Expparasitol 121(3): 238-241.

143. Tuck S, Francis R (2009) Testosterone, bone and osteoporosis Advances in the management of testosterone deficiency. Karger 137: 123-132.

144. Uniprot(2017)Taxonomy-Piroplasmida(Piroplasmids).

145. Webster JP (2001) Rats, cats, people and parasites: the impact of latent toxoplasmosis on behaviour. Microbesinfect 3(12): 10371045.

146. Widmann FK(1990) Technical Manual. Washington DC: American Association of Blood Banks.

147. Wilson M, Remington JS, Clavet C, Varney G, Press C, et al.(1997) Evaluation of six commercial kits for detection of human immunoglobulin M. antibodies to Toxoplasma gondii. The FDA Toxoplasmosis Ad Hoc Working Group. J Clin Microbiol 35(12): 3112-3115.
148. Wolf A, Cowen D, Paige BH (1939)Toxoplasmic encephalomyelitis: III. A new case of granulomatous encephalomyelitis due to a protozoon. Am jpathol15(6): 657-694.

149. Zaini RG, Ismail KA, Dahlawi H (2016) Seroprevalence of Toxoplasma gondii among AIDS Patients in Saudi Arabia. World Journal of AIDS 6(03): 81 .

150. Zhiburt EB, Ionova AI, Danil'chenko VV, Serebrianaia NB, Bel'gesov NV, et al. (1996) The spread of antibodies to cytomegalovirus and Toxoplasma among donors of blood components.ZhMikrobiol Epidemiol Immunobiol1: 59-61.

151. Zhou P, Zhang H, Lin RQ Zhang DL, Song HQ (2009) Genetic characterization of Toxoplasma gondii isolates from China. InJParasitol58(2):193-195.

152. Zuber P, Jacquier P (1994) Epidemiology of toxoplasmosis: worldwide status. Schweiz Med Wochenschr Suppl 65: (19S-22S).

\section{Your next submission with Juniper Publishers will reach you the below assets}

- Quality Editorial service

- Swift Peer Review

- Reprints availability

- E-prints Service

- Manuscript Podcast for convenient understanding

- Global attainment for your research

- Manuscript accessibility in different formats

( Pdf, E-pub, Full Text, Audio)

- Unceasing customer service

Track the below URL for one-step submission https://juniperpublishers.com/online-submission.php 